\title{
EFEKTIVITAS MODEL KOOPERATIF TIPE ROTATING TRIO EXCHANGE DALAM PEMBELAJARAN LOGARITMA
}

\author{
Muhammad Nurhusain \\ STKIP YPUP Makassar, Jl. Andi Tonro No. 17 Makassar, Sulawesi Selatan, Indonesia \\ E-mail: zein.alhusain@gmail.com
}

\begin{abstract}
Abstrak
Siswa yang mempelajari matematika seharusnya dapat mengkonstrak konsep matematika secara mandiri. Model pembelajaran kooperatif tipe Rotaring Trio Exchange memungkinkan siswa untuk mampu mengkonstruak konsep matematika. Tujuan penelitian ini adalah untuk mengetahui keefektifan model pembelajaran kooperatif rotating-trio-exchange dalam pembelajaran matematika khususnya materi logaritma. Penelitian ini merupakan penelitian pra eksperimental dengan menggunakan rancangan pretest-posttest-only group design. Populasi dari penelitian ini adalah siswa kelas X Sekolah Mengengah Atas (SMA). Sampel terdiri dari 21 siswa kelas XB SMA YP-PGRI 3 Makassar. Pengumpulan data dilakukan sebanyak dua kali, yaitu sebelum dan sesudah pelaksanaan pembelajaran. Data yang diperoleh kemudian dianalisis secara deskriptif dan inferensial. Hasil penelitian menunjukkan bahwa anggota kelompok siswa yang melakukan diskusi secara bergilir selama setiap sesi diskusi sambil mengkonstrak konsep matematika dapat meningkatkan aktivitas siswa, menghasilkan pembelajaran yang lebih bermakna dan memperoleh hasil belajar yang lebih baik. Dengan demikian, model pembelajaran kooperatif rotating trio exchange efektif dalam meningkatkan hasil belajar siswa dalam pembelajaran logaritmik.
\end{abstract}

Kata Kunci: efektivitas, kooperatif, rotating-trio-exchange, pembelajaran matematika

\begin{abstract}
The mathematics students should construct their own mathematical concepts. The rotating trio exchange model of cooperative learning enables students to construct mathematical concepts. The purpose of this study is to determine the effectiveness of the rotating-trioexchange cooperative learning model in the learning of mathematics, particularly logarithmic material. This research is a pre-experimental study using a pretest-posttestonly group design. The population of this study was students of class X SMA. The sample consisted of 21 students from class XB SMA YP-PGRI 3 Makassar. Data collection occurred twice, before and after the implementation of teaching and learning. The data were analyzed both descriptively and inferentially. The findings indicated that rotating group members during each discussion session while constructing mathematical concepts could elicit student activity, resulting in more meaningful learning and improved learning outcomes. Thus, the rotating trio exchange cooperative learning model is effective for learning logarithmic.
\end{abstract}

Keywords: effectiveness, cooperative, rotating-trio-exchange, mathematics learning 


\section{PENDAHULUAN}

Matematika merupakan mata pelajaran yang penting dalam membentuk pribadi siswa yang berkualitas. Matematika sebagai suatu sarana berpikir dalam mendalami sesuatu secara sistematis, rasional, kritis, logis, dan melatih siswa agar dapat memecahkan masalah yang dialami dalam kehidupan. Hal tersebut sejalan dengan Hudojo (Karmila \& Ekawati, 2016), yang menyatakan bahwa matematika merupakan suatu alat untuk mengembangkan cara berpikir, karena matematika sangat diperlukan, baik untuk kehidupan sehari-hari maupun dalam menghadapi kemajuan IPTEK, sehingga potensi diri yang dimiliki siswa diharapkan dapat berkembang. Oleh karena itu, untuk mencapai tingkat kualitas yang lebih baik, pembelajaran matematika harus dapat terus dikembangkan. Diharapkan dengan adanya peningkatan kualitas pembelajaran matematika, maka akan memberi dampak positif bagi peningkatan kualitas pendidikan di Indonesia.

Namun, menurut Frensista et al., (2017), matematika sering dinyatakan sebagai mata pelajaran yang sulit untuk dipahami oleh siswa. Hal ini tampak pada hasil belajar siswa yang tidak sesuai dengan yang diharapkan. Selama ini, umumnya siswa hanya menghafal rumus pada waktu menyelesaikan soal matematika. Di lain pihak, matematika merupakan pelajaran yang bersifat abstrak, sehingga siswa membutuhkan pemahaman konsep dalam mempelajarinya.

Faktor lain yang biasa berpengaruh terhadap hasil belajar matematika siswa adalah guru kurang tepat dalam memilih model yang digunakan dalam pembelajaran. Menurut Tanujaya et al., (2017), model pembelajaran yang berpusat pada guru kurang efektif jika digunakan dalam pembelajaran matematika. Hal ini berpengaruh selama proses pembelajaran dan dapat berakibat pada menurunnya hasil belajar siswa. Hasil belajar akan tumbuh dan terpelihara jika proses pembelajaran dilaksanakan secara bervariasi.

Berdasarkan hasil wawancara, pembelajaran seperti ini juga terjadi di SMA YPPGRI 3 MAKASSAR. Hasil belajar siswa (terutama di kelas X.B, sebanyak 21 siswa) pada bidang studi matematika masih kurang dari 75 atau berada di bawah Kriteria Ketuntasan Minimal (KKM). Menurut keterangan yang diperoleh dari guru, terdapat beberapa kendala sehingga upaya meningkatkan hasil belajar matematika belum optimal. Motivasi siswa yang rendah menjadi salah satu kendala yang dihadapi. Selain itu, siswa kurang dapat memahami materi dikarenakan siswa kurang aktif dalam pembelajaran, dan 
siswa hanya menghafal materi sehingga mudah melupakan materi yang diajarkan. Dengan cara seperti itu, siswa akan mudah merasa bosan dan kesulitan mempelajari matematika. Olehnya itu, diperlukan kreativitas guru dalam memilih model atau metode pembelajaran yang melibatkan siswa secara aktif dan efektif digunakan dalam pembelajaran matematika. Model atau metode pembelajaran yang efektif digunakan apabila memenuhi kriteria keefektifan. Menurut Jeranah (2017) kriteria keefektifan yang perlu dipenuhi adalah: (1) hasil belajar siswa setelah diberi perlakuan lebih baik dari sebelum diberi perlakuan, (2) Aktivitas guru dalam mengelola pembelajaran pada kategori baik, (3) Aktivitas siswa selama pembelajaran pada kategori baik, dan (4) respon siswa terhadap penerapan perlakuan pada kategori positif.

Pendapat lain dari Wahyuddin \& Erliani (2019) menyatakan bahwa keefektifan pembelajaran dapat ditinjau dari hasil belajar yang mencapai KKM, tuntas secara klasikal, terjadi peningkatan hasil belajar dari pretes ke postes dengan nilai gain minimal pada kategori sedang, siswa aktif dalam pembelajaran, pembelajaran terlaksana dengan baik, dan siswa memberikan respon positif terkait model pembelajaran yang diterapkan”. Selain itu, Karmila \& Ekawati, (2016) mengatakan bahwa pembelajran dapat dikatakan efektif jika memenuhi kriteria: hasil belajar mencapai KKM, terjadi peningkatan hasil belajar, siswa aktif dalam pembelajaran, dan respon siswa positif.

Berdasarkan beberapa teori tersebut, dapat dinyatakan bahwa suatu pembelajaran dikatakan efektif jika proses pembelajaran sudah berlangsung sesuai dengan ketetapan yang ada dan membuahkan hasil yang memuaskan. Jadi, efektifitas dimaksudkan sejauh mana proses pencapaian hasil dari tujuan yang diharapkan tercapai yaitu dengan kriteria: (1) Rata-rata hasil balajar siswa lebih tinggi dari nilai KKM; (2) Ketuntasan klasikal terpenuhi yaitu 85\% siswa mencapai ketuntasan individu; (3) Peningkatan hasil belajar matematika siswa dari pretest ke posstest minimal berada pada kategori sedang yaitu $\mathrm{g} \geq$ 0,3; (4) Aktivitas siswa minimal pada kategori aktif; (5) Keterlaksanaan pembelajaran minimal pada kategori baik; (6) Respon siswa minimal berada pada kategori positif.

Perlu diketahui bahwa tidak ada keharusan untuk menetapkan 6 (enam) kriteria keefektifan. Namun dapat diklaim bahwa dengan memperketat kriteria menjadi enam, akan mampu memotret keefektifan pembelajaran dengan lebih baik dibandingkan dengan penelitian sebelumnya. Alasannya adalah enam kriteria keefektifan dalam penelitian ini dirangkum dari penelitian sebelumnya, sehingga dapat menutupi celah kriteria yang tidak 
digunakan. Enam kriteria tersebut sekaligus menjadi salah satu pembeda dengan tiga penelitian serupa sebelumnya oleh Jeranah (2017), Karmila \& Ekawati, (2016) dan Wahyuddin \& Erliani (2019) yang hanya menggunakan kurang dari 6 (enam) kriteria.

Pencapaian keefektifan pembelajaran memerlukan suatu model pembelajaran yang efektif. Salah satu model pembelajaran yang diharapkan dapat melibatkan siswa secara aktif dan efektif dalam pembelajaran matematika adalah model pembelajaran kooperatif. Menurut Arends (Rismawati \& Jasman, 2014), model pembelajaran kooperatif dikembangkan untuk mencapai sekurang-kurangnya tiga tujuan pembelajaran penting, yaitu hasil belajar akademik, penerimaan terhadap perbedaan individu, dan pengembangan keterampilan sosial. Selanjutnya Sani (Nurhusain, 2017), menyatakan bahwa aktivitas pembelajaran kooperatif menekankan pada kesadaran siswa untuk saling membantu mencari dan mengolah informasi, mengaplikasikan pengetahuan dan keterampilan. Selain itu, menurut Jhonson \& Jhonson (Muswaroh et al., 2018), mengungkapkan bahwa suasana belajar pada pembelajaran kooperatif menghasilkan prestasi yang lebih tinggi, hubungan yang lebih positif, dan penyesuaian psikologis yang lebih baik.

Tanujaya dan Mumu (2019), lebih lanjut menyatakan bahwa model pembelajaran kooperatif merupakan model pembelajaran yang menuntut siswa bertanggung jawab terhadap diri sendiri dan kelompoknya. Dengan menggunakan model pembelajaran tersebut, siswa akan lebih mudah menemukan dan memahami konsep-konsep yang sulit. Mereka akan berdiskusi dengan teman sebaya secara teratur dan bekerja dalam kelompok untuk saling membantu dalam memecahkan masalah yang kompleks

Terdapat beberapa model pembelajaran kooperatif terdiri dari beberapa tipe, salah satunya yaitu tipe rotating trio exchange (RTE). Menurut Dipayana et al., (2014) Model pembelajaran kooperatif tipe rotating trio exchange memiliki beberapa keunggulan diantaranya struktur yang jelas yang dapat memungkinkan siswa untuk berbagi dengan pasangan dalam kelompoknya dengan waktu yang teratur; siswa mempunyai banyak kesempatan untuk mengolah informasi yang diperoleh; dan tidak terdapat kebosanan pada saat proses pembelajaran karena siswa akan dirotasi.

Lebih lanjut, Widyawati et al., (2016), menyatakan bahwa ciri utama dari rotating trio exchange (RTE) ini adalah adanya pemberian kesempatan bagi siswa untuk berdiskusi dengan beberapa atau sebagian besar teman kelasnya dengan cara merotasi 
kelompok pada setiap sesi diskusi. Sementara itu, pada setiap sesi diskusi diberikan latihan soal atau pertanyaan dengan tingkat kesulitan yang meningkat". Selanjutnya, Frensista et al., (2017) mengemukakan bahwa "model pembelajaran tipe rotating trio exchange (RTE) merupakan model yang digunakan dalam diskusi tentang berbagai masalah dengan beberapa teman kelasnya. Dalam model ini, akan terjadi perputaran anggota kelompok dalam mengkonstruksi konsep matematika, yang diharapkan dapat membangkitkan keaktifan siswa sehingga tercipta pembelajaran yang bermakna".

Pratama et al., (2015) melalui hasil penelitiannya menyatakan bahwa model pembelajaran kooperatif tipe rotating trio exchange memberikan pemahaman konsep bangun ruang lebih baik dibandingkan dengan model pembelajaran kooperatif tipe STAD. Selain itu, Nuraeni \& Afriansyah (2016) mengemukakan berdasarkan hasil penelitiannya bahwa kemampuan pemahaman matematis siswa yang mendapatkan model pembelajaran kooperatif tipe RTE lebih baik dibandingkan dengan kemampuan pemahaman matematis yang mendapatkan pembelajaran konvensional. Selain itu, Yuliati et al., (2016) mengemukakan bahwa penerapan model pembelajaran kooperatif tipe rotating trio exchange meningkatkan hasil belajar peserta didik. Lebih lanjut Sadikin (2017) dengan hasil penelitiannya bahwa penggunaan strategi pembelajaran rotating trio exchange berpengaruh terhadap hasil belajar mahasiswa pada aspek kognitif, afektif dan psikomotorik.

Dengan demikian, beberapa penelitian yang menggunakan model pembelajaran kooperatif tipe rotating trio exchange hanya berfokus pada hasil belajar dan kemampuan pemahaman matematis yang sesungguhnya juga merupakan hasil dari belajar matematika. Oleh karena itu maka fokus dalam penelitian ini lebih diperluas, tidak hanya pada hasil belajar saja melainkan juga pada aktivitas siswa, keterlaksanaan pembelajaran dan respon siswa terhadap penerapan model pembelajaran kooperatif tipe rotating trio exchange. Fokus tersebut diramu menjadi kriteria keefektifan pembelajaran.

Berdasarkan beberapa uraian terdahulu, maka peneliti melakukan penelitian yang bertujuan untuk mengetahui efektifitas model pembelajaran kooperatif tipe rotating trio exchange dalam pembelajaran matematika. Manfaat yang diharapkan dari hasil penelitian ini adalah memperoleh model pembelajaran yang efektif digunakan dalam pembelajaran matematika, sehingga dapat menjadi salah satu pilihan efektif oleh guru dalam melakukan proses pembelajaran. 


\section{METODE PENELITIAN}

Penelitian ini merupakan jenis penelitian pre-experiment. Desain yang digunakan adalah pretest-posttest only group design, yang terdiri dari tiga langkah, yakni memberikan tes untuk mengukur kemampuan awal siswa (pretest), menentukan sampel penelitian untuk dikenakan perlakuan eksperimen, dan melaksanakan tes setelah pelaksanaan pembelajaran untuk mengukur hasil belajar setelah perlakuan (posttest). Perbedaaan-perbedaan hasil penerapan perlakuan eksperimen, ditentukan melalui perbandingan skor-skor pretest dan posttest dengan alat ukur yang relatif identik atau sama (Sudjana dan Ibrahim, 2012). Instrumen yang digunakan untuk mengukur skor pretest dan posttest merupakan instrumen tes yang berbeda namun dengan tingkat kesukaran yang setara serta menggunakan materi yang sama.

\section{Populasi dan Sampel}

Siswa kelas X SMA YP-PGRI 3 Makassar terdiri dari 2 (dua) kelas berjumlah 42 (empat puluh dua) orang yang merupakan populasi terjangkau dari penelitian ini. Sampel dipilih menggunakan teknik cluster random sampling karena dua kelas tersebut telah terbentuk dari awal, dan untuk menghindari kekacauan administrasi, maka sampel tidak dipilih secara perorangan untuk membentuk kelas baru. Selain itu, kedua kelas tersebut homogen dan masing-masing kelas tidak memiliki ciri-ciri khusus yang membedakan antara satu dengan yang lain. Kelas yang terpilih secara acak/random sebagai sampel adalah kelas $\mathrm{X}_{\mathrm{B}}$.

\section{Instrumen dan Teknik Pengumpulan Data}

Instrumen yang digunakan dalam penelitian ini berupa: (1) Tes hasil belajar berbentuk soal uraian, yang digunakan melalui pemberian tes kepada siswa sebelum dan setelah diberikan perlakuan. Kedua tes tersebut merupakan soal yang setara; (2) Lembar aktivitas siswa digunakan untuk mencatat partisipasi siswa dalam pembelajaran RTE. Penggunaan instrument ini dilaksanakan dengan memperhatikan aktivitas siswa saat proses pembelajaran berlangsung pada setiap pertemuan; (3) Angket respon siswa, yang digunakan untuk mengetahui respon siswa terhadap model pembelajaran RTE. Pengukuran instrument ini dilakukan dengan cara dibagikan kepada setiap siswa sebelum tes akhir setelah perlakuan diberikan; (4) Lembar observasi keterlaksanaan pembelajaran, 
digunakan untuk memperoleh data kemampuan guru dalam pelaksanaan dan pengelolaan pembelajaran berdasarkan model pembelajaran RTE. Data tersebut diperoleh dengan melakukan observasi terhadap aktivitas guru dalam mengelola pembelajaran saat proses pembelajaran berlangsung di setiap pertemuan.

\section{Teknik Analisis Data}

Analisis hasil belajar yang diperoleh siswa meliputi: rata-rata (mean) dan simpangan baku (standard deviation). Kriteria ketuntasan individu yaitu nilai siswa mencapai atau melebihi nilai Kriteria Ketuntasan Minimal (KKM) yang telah ditetapkan oleh SMA YP-PGRI 3 Makassar yaitu sebesar 75, sebagaimana disajikan pada Tabel 1.

Tabel 1. Kategori Ketuntasan Hasil Belajar

\begin{tabular}{cc}
\hline Interval Nilai Hasil Belajar & Kategori \\
\hline $0-74$ & Tidak Tuntas \\
$75-100$ & Tuntas \\
\hline
\end{tabular}

Selain itu, dilakukan pengujian terhadap ketuntasan klasikal, yang merupakan ukuran ketuntasan yang dicapai suatu kelas. Kriteria ketuntasan klasikal menurut Trianto (2010); Nurhusain \& Hadi, (2021), yaitu minimal 85\% dari banyaknya siswa mencapai ketuntasan individu. Analisis secara statistik inferensi berupa uji t, juga dilakukan untuk memperkuat hasil analisis secara deskriptif.

Peningkatan hasil belajar dievaluasi dengan menggunakan Uji Gain, untuk menunjukkan perubahan positif yaitu terjadi peningkatan nilai hasil belajar setelah penerapan model pembelajaran rotating trio exchange. Rumus yang digunakan untuk menentukan nilai Gain adalah:

$$
\text { Gain }=\frac{\text { nilai postest }- \text { nilai pretest }}{\text { nilai maksimal (ideal) }- \text { nilai pretest }}
$$

Keberhasilan suatu pembelajaran dapat terlihat dari normalisasi nilai gain. Kriteria yang digunakan yaitu nilai Gain minimal berada pada kategori sedang atau nilai $g \geq 0,3$. Pengelompokkan keberhasilan suatu pembelajaran menurut Sundayana (2015) berdasarkan nilai Gain disajikan pada Tabel 2. 
Tabel 2. Pengkategorian Nilai Gain

\begin{tabular}{cc}
\hline Interval Nilai Gain & Kategori \\
\hline $\mathrm{g}<0,3$ & Rendah \\
$0,3 \leq \mathrm{g}<0,7$ & Sedang \\
$0,7 \leq \mathrm{g}$ & Tinggi \\
\hline
\end{tabular}

Data aktivitas siswa dianalisis dengan menggunakan rumus:

$$
P_{A S}=\frac{f}{N} \times 100 \%
$$

dimana:

$\mathrm{P}_{\mathrm{AS}}=$ Persentase aktivitas siswa

$f=$ Frekuensi masing-masing aspek observasi aktivitas siswa yang diperoleh

$\mathrm{N}=$ Frekuensi maksimal masing-masing aspek observasi aktivitas siswa

Kriteria yang digunakan untuk menentukan kategori aktivitas siswa $\left(P_{A S}\right)$ minimal berada pada kategori aktif atau $P_{A S} \geq 70 \%$, sebagaimana yang dikemukakan oleh Supriyadi (2013), yang disajikan pada Tabel 3.

Tabel 3. Kategori Aspek Aktivitas Siswa

\begin{tabular}{cc}
\hline Persentase \% & Kategori \\
\hline $85-100$ & Sangat aktif \\
$70-84$ & Aktif \\
$55-69$ & Sedang \\
$50-54$ & Kurang aktif \\
$0-49$ & Sangat Kurang \\
\hline
\end{tabular}

Penentuan kategori keterlaksanaan pembelajaran $\left(P_{K P}\right)$ minimal berada pada kategori baik atau $P_{K P} \geq 70 \%$, sebagaimana yang dikemukakan oleh Supriyadi (2013), yang disajikan pada Tabel 4.

Tabel 4. Kriteria Persentase Keterlaksanaan Pembelajaran

\begin{tabular}{cc}
\hline Persentase \% & Kategori \\
\hline $85-100$ & Sangat baik \\
$70-86$ & Baik \\
\hline
\end{tabular}




\begin{tabular}{cc}
\hline Persentase \% & Kategori \\
\hline $55-69$ & Sedang \\
$50-54$ & Kurang baik \\
$0-49$ & Sangat Kurang \\
\hline
\end{tabular}

Data respon siswa sesuai hasil angket dianalisis untuk menentukan presentase dari respons siswa dengan menggunakan rumus:

$$
P_{R S}=\frac{f}{N} \times 100 \%,
$$

dimana:

$\mathrm{P}_{\mathrm{RS}}=$ Persentase respon siswa dengan jawaban ya

$f \quad=$ Frekuensi siswa dengan jawaban ya

$\mathrm{N} \quad=$ Total siswa yang mengisi angket

Penentuan kategori respon siswa $\left(P_{R S}\right)$ minimal berada pada kategori positif atau $P_{R S} \geq 70 \%$, sebagaimana yang dikemukakan oleh Supriyadi (2013), yang disajikan pada Tabel 5.

Tabel 5. Kategori Respon Siswa

\begin{tabular}{cc}
\hline Persentase \% & Kategori \\
\hline $85-100$ & Sangat Positif \\
$70-86$ & Positif \\
$55-69$ & Sedang \\
$50-54$ & Kurang positif \\
$0-49$ & Sangat Kurang \\
\hline
\end{tabular}

\section{HASIL DAN PEMBAHASAN}

\section{Deskripsi Rata-rata Hasil Belajar}

Hasil analisis statistik deskriptif untuk data hasil belajar pre-test dan post-test sebagaimana disajikan pada Tabel 6 menunjukkan hasil yang diperoleh siswa pada posttest lebih baik dari hasil pre-test. 
Journal of Honai Math, Vol. 4, No. 1, pp. 19-34, April 2021

Nurhusain, Efektivitas Model Kooperatif Tipe Rotating Trio Exchange dalam Pembelajaran Logaritma

Tabel 6. Deskripsi Hasil Belajar Matematika Siswa

\begin{tabular}{lcc}
\hline \multicolumn{1}{c}{ Statistik } & Nilai Statistik Pre-Test & Nilai Statistik Post-Test \\
\hline Ukuran sampel & 21 & 21 \\
Skor ideal & 100 & 100 \\
Rata-rata & 58,38 & 82,143 \\
Standar deviasi & 9,261 & 8,193 \\
\hline
\end{tabular}

Berdasarkan Tabel 6, rata-rata dari nilai hasil belajar setelah penerapan model pembelajaran kooperatif tipe rotating trio exchange cukup tinggi, yaitu 82,143 dengan simpangan baku sebesar 8,193 . Hal tersebut menunjukkan bahwa kemampuan siswa memahami materi yang diajarkan telah mencapai kriteria ketuntasan minimal (KKM) yaitu 75. Berdasarkan rata-rata hasil pre-test dan post-test, diperoleh rata-rata hasil belajar siswa setelah (post-test) lebih tinggi dari sebelum (pretest) penerapan model pembelajaran kooperatif tipe rotating trio exchange (RTE).

Selain itu, hasil analisis statistik deskriptif tersebut diperkuat dengan hasil analisis statistik inferensial, sebagaimana disajikan pada Tabel 7.

Tabel 7. Hasil Uji t untuk Hasil Belajar Matematika Siswa setelah Perlakuan

\begin{tabular}{|c|c|c|c|c|c|c|}
\hline & \multicolumn{6}{|c|}{ Test Value $=0$} \\
\hline & \multirow[b]{2}{*}{$\mathrm{t}$} & \multirow[b]{2}{*}{$\mathrm{df}$} & \multirow[b]{2}{*}{ Sig. (2-tailed) } & \multirow[b]{2}{*}{ Mean Difference } & \multicolumn{2}{|c|}{$\begin{array}{c}\text { 95\% Confidence Interval of the } \\
\text { Difference }\end{array}$} \\
\hline & & & & & Lower & Upper \\
\hline Post test & 45,944 & 20 &, 000 & 82,143 & 78,41 & 85,87 \\
\hline
\end{tabular}

Berdasarkan Tabel 7, nilai P kurang dari 0.05 (p-value: 0.00). Hal ini menunjukkan bahwa hipotesis awal $\left(\mathrm{H}_{0}: \mu_{2} \leq 75\right)$ ditolak atau menerima hipotesis alternatif $\left(\mathrm{H}_{1}: \mu_{2}>\right.$ 75). Artinya, tingkat pemahaman siswa terhadap materi logaritma setelah diajar melalui model pembelajaran kooperatif tipe RTE lebih tinggi dari KKM.

Hasil penelitian ini terkait penerapan model pembelajaran kooperatif tipe RTE terhadap hasil belajar sejalan dengan hasil penelitian oleh Agustini et al., (2018) bahwa terdapat pengaruh positif penggunaan model pembelajaran ini terhadap hasil belajar siswa. Hal ini ditunjukkan dengan siswa yang diajarkan dengan model pembelajaran kooperatif tipe RTE memiliki skor rata-rata post-test lebih besar dibandingkan dengan skor rata-rata posttest siswa yang diajarkan dengan pembelajaran konvensional. 
Selanjutnya, hasil penelitian Hasanah et al., (2019), turut membenarkan bahwa pembelajaran matematika menggunakan model kooperatif RTE berpengaruh terhadap hasil belajar. Sejalan dengan hasil penelitian tersebut, Yahya \& Bakri (2020) mengemukakan bahwa model pembelajaran ini dapat meningkatkan hasil belajar matematika siswa. Dengan demikian dapat dinyatakan bahwa kriteria keefektifan yang pertama terpenuhi.

\section{Deskripsi Ketuntasan Klasikal}

Perbandingan hasil belajar pre-test dan post-test berdasarkan persentase ketuntasan individu siswa disajikan pada Tabel 8.

Tabel 8. Persentase Ketuntasan Hasil Belajar Siswa

\begin{tabular}{lcccccc}
\hline & $\begin{array}{c}\text { Jumlah } \\
\text { siswa }\end{array}$ & $\begin{array}{c}\text { Siswa } \\
\text { tuntas }\end{array}$ & $\%$ & Kriteria & Kategori & Keterangan \\
\hline Pre-test & 21 & 2 & 9,52 & $\%<85 \%$ & Tidak Tuntas & Tidak Efektif \\
Post-test & 21 & 19 & 90,48 & $\% \geq 85 \%$ & Tuntas & Efektif \\
\hline
\end{tabular}

Pada Tabel 8, tampak bahwa persentase ketuntasan hasil belajar matematika siswa sebesar 90,48\%, atau ketuntasan klasikal minimal sebesar 85\% terpenuhi. Hal ini mengandung pengertian bahwa hasil belajar matematika siswa mencapai ketuntasan klasikal apabila pembelajaran dilaksanakan dengan menerapkan model pembelajaran kooperatif tipe RTE, sehingga kriteria keefektifan yang kedua terpenuhi.

\section{Deskripsi Peningkatan Hasil Belajar Matematika}

Peningkatan hasil belajar dari pre-test ke post-test dianalisis dengan menggunakan nilai gain, diperoleh nilai gain sebesar 0,563 berada pada kategori sedang, berdasarkan kriteria pada Tabel 2. Hasil tersebut diperkuat dengan hasil analisis statistik inferensial dengan taraf signifikansi 5\% (p-value: $0,00<0,05$ ), sebagaimana disajikan pada Tabel 9.

Tabel 9. Hasil Uji t untuk Nilai Gain

\begin{tabular}{|c|c|c|c|c|c|c|}
\hline & \multicolumn{6}{|c|}{ Test Value $=0$} \\
\hline & \multirow[b]{2}{*}{$\mathrm{t}$} & \multirow[b]{2}{*}{$\mathrm{Df}$} & \multirow[b]{2}{*}{ Sig. (2-tailed) } & \multirow[b]{2}{*}{ Mean Difference } & \multicolumn{2}{|c|}{$\begin{array}{l}\text { 95\% Confidence Interval of the } \\
\text { Difference }\end{array}$} \\
\hline & & & & & Lower & Upper \\
\hline Gain & 12,035 & 20 & ,000 & ,56333 & ,4657 & 6610 \\
\hline
\end{tabular}


Berdasarkan Tabel 9, diperoleh bahwa hipotesis awal $\left(\mathrm{H}_{0}: \mu_{\mathrm{g}} \leq 0.3\right)$ ditolak atau menerima hipotesis alternatif $\left(\mathrm{H}_{1}: \mu_{\mathrm{g}}>0.3\right)$. Hal ini berarti bahwa nilai gain lebih besar dari 0,3. Mengacu pada kriteria nilai gain, maka dapat disimpulkan bahwa peningkatan dari nilai pretest ke posttest berada pada kategori sedang. Hal ini menunjukan bahwa hasil belajar siswa sebelum menerapkan model pembelajaran kooperatif tipe rotating trio exchange (RTE) (pretest) mengalami peningkatan setelah menerapkan model pembelajaran kooperatif tipe rotating trio exchange (RTE) (posttest). Dengan demikian dapat dinyatakan bahwa kriteria keefektifan yang ketiga terpenuhi.

\section{Deskripsi Aktivitas Siswa}

Hasil analisis aktivitas siswa selama pembelajaran melalui penerapan model pembelajaran kooperatif tipe rotating trio exchange (RTE) disajikan pada Tabel 10.

Tabel 10. Analisis Deskriptif Aktivitas Siswa

\begin{tabular}{cccccccccc}
\hline \multicolumn{4}{c}{ Skor yang Diperoleh } & $\begin{array}{c}\text { Skor } \\
\text { Maksimun }\end{array}$ & $\begin{array}{c}\text { Persentase } \\
(\%)\end{array}$ & Kategori \\
\cline { 1 - 2 } & \multicolumn{3}{c}{ Pertemuan } & & Total & & Aktif \\
\hline I & II & III & IV & V & VI & 178 & 210 & 84,76 & A \\
\hline 31 & 27 & 30 & 29 & 30 & 31 & & & & \\
\hline
\end{tabular}

Berdasarkan informasi pada Tabel 10, diketahui bahwa aktivitas siswa dengan menerapkan model pembelajaran kooperatif tipe rotating trio exchange (RTE) menunjukan rata-rata persentase aktivitas siswa yaitu 84,76\%. Hasil tersebut menunjukkan keaktifan dan partisipasi siswa selama proses penerapan pembelajaran kooperatif tipe rotating trio exchange (RTE) berada pada kategori aktif. Hasil ini sesuai dengan hasil penelitian oleh Hasanah et al., (2019) yang mengemukakan bahwa siswa aktif dengan saling membantu dalam menguasai materi pelajaran dalam pembelajaran matematika yang dilaksanakan dengan menggunakan model pembelajaran kooperatif tipe rotating trio exchange (RTE). Selanjutnya, Yahya \& Bakri (2020) juga mengemukakan bahwa penggunaan model pembelajaran kooperatif tipe rotating trio exchange dapat meningkatkan aktivitas belajar matematika siswa. Dengan demikian dapat dinyatakan bahwa kriteria keefektifan yang keempat terpenuhi. 


\section{Deskripsi Keterlaksanaan Pembelajaran}

Hasil pengamatan keterlaksanaan pembelajaran selama penerapan model pembelajaran kooperatif tipe rotating trio exchange (RTE) disajikan pada Tabel 11.

Tabel 11. Analisis Deskriptif Keterlaksanaan Pembelajaran

\begin{tabular}{|c|c|c|c|c|c|}
\hline \multicolumn{3}{|c|}{ Skor yang Diperoleh } & \multirow{2}{*}{$\begin{array}{c}\text { Skor } \\
\text { Maksimun }\end{array}$} & \multirow{2}{*}{$\begin{array}{c}\text { Persentase } \\
\text { (\%) }\end{array}$} & \multirow{2}{*}{ Kategori } \\
\hline & Pertemuan & Total & & & \\
\hline & $\begin{array}{lllll}\text { II } & \text { III } & \text { IV } & \text { V } & \text { VI }\end{array}$ & \multirow{2}{*}{59} & \multirow{2}{*}{72} & \multirow{2}{*}{81,94} & \multirow{2}{*}{ Baik } \\
\hline & $\begin{array}{lllll}10 & 11 & 11 & 9 & 10\end{array}$ & & & & \\
\hline
\end{tabular}

Tabel 11 menyajikan informasi bahwa rata-rata persentase keterlaksanaan pembelajaran yaitu sebesar $81,94 \%$. Hasil analisis keterlaksanaan pembelajaran menunjukkan bahwa keterlaksanaan pembelajaran kooperatif tipe rotating trio exchange (RTE) berada pada kategori baik. Hasil ini sesuai dengan hasil penelitian Hasanah et al., (2019) yang menyatakan bahwa dalam pembelajaran matematika menggunakan model pembelajaran kooperatif tipe rotating trio exchange (RTE), guru melakukan pembelajaran dengan baik sesuai dengan tahapan RPP. Dengan demikian dapat dinyatakan bahwa kriteria keefektifan yang kelima terpenuhi.

\section{Deskripsi Respon Siswa}

Hasil analisis respon siswa berdasarkan angket yang dibagikan kepada siswa mengikuti pembelajaran disajikan pada Tabel 12.

Tabel 12. Analisis Deskriptif Respon Siswa

\begin{tabular}{|c|c|c|c|c|c|}
\hline \multicolumn{3}{|c|}{ Skor yang Diperoleh } & \multirow{2}{*}{$\begin{array}{c}\text { Skor } \\
\text { Maksimun }\end{array}$} & \multirow{2}{*}{$\begin{array}{c}\text { Persentase } \\
\text { (\%) }\end{array}$} & \multirow{2}{*}{ Kategori } \\
\hline & Indikator & Total & & & \\
\hline I & $\begin{array}{llll}\text { II } & \text { III } & \text { IV } & \text { V }\end{array}$ & \multirow{2}{*}{82} & \multirow{2}{*}{105} & \multirow{2}{*}{78,09} & \multirow{2}{*}{ Positif } \\
\hline 20 & $\begin{array}{llll}6 & 17 & 19 & 20\end{array}$ & & & & \\
\hline
\end{tabular}

Tabel 12 menunjukkan bahwa rata-rata respon siswa sebesar 78,09\%. Hal ini menunjukan bahwa respon siswa berada pada kategori positif. Hal ini sejalan dengan (Nuraeni \& Afriansyah, 2016) yang menyatakan bahwa sikap siswa yang mendapatkan model pembelajaran kooperatif tipe RTE memiliki sikap yang baik terhadap pembelajaran matematika. Dengan demikian kriteria keefektifan yang keenam ini juga terpenuhi. 


\section{KESIMPULAN DAN SARAN}

Model pembelajaran kooperatif tipe rotating trio exchange (RTE) efektif digunakan dalam pembelajaran matematika, khususnya dalam pembelajaran Logaritma. Rata-rata hasil belajar siswa setelah menerapakan model pembelajaran kooperatif tipe rotating trio exchange (RTE) lebih tinggi secara signifikan dari nilai KKM, dan kriteria ketuntasan klasikal terpenuhi. Terdapat peningkatan nilai hasil belajar yang signifikan dari hasil pretest ke post-test, dengan nilai gain pada kategori sedang. Aktivitas siswa tergolong pada kategori aktif. Keterlaksanaan pembelajaran pada kategori baik, serta respon siswa pada kategori positif.

Saran untuk peneliti yang ingin melanjutkan penelitian agar menggunakan kelas kontrol untuk mengontrol penerapan model pembelajaran kooperatif tipe rotating trio exchange (RTE). Bagi praktisi pendidikan terutama tenaga pengajar bidang studi matematika, model pembelajaran kooperatif tipe rotating trio exchange (RTE) dapat menjadi salah satu alternatif yang efektif diterapkan dalam pembelajaran matematika.

\section{DAFTAR PUSTAKA}

Agustini, R., Kendek, Y., \& Kamaluddin, K. (2018). Pengaruh Model Pembelajaran Kooperatif Tipe Rotating Trio Exchange (RTE) terhadap Hasil Belajar Fisika Kelas XI SMA Negeri 1 Palu. JPFT (Jurnal Pendidikan Fisika Tadulako Online), 6(3), 10. https://doi.org/10.22487/j25805924.2018.v6.i3.11069

Dipayana, I. D., Japa, I. G. N., \& Suarjana, I. (2014). Pengaruh Strategi Pembelajaran Rotating Trio Exchange ( Rte ) Terhadap Hasil Belajar Matematika. Jurnal Mimbar PGSD Universitas Pendidikan Ganesha Jurusan PGSD, 2(1), 1-10.

Frensista, D., Trapsilasiw, D., \& L, N. D. S. (2017). Penerapan Model Pembelajaran Kooperatif Dengan Strategi Rotating Trio Exchange Untuk Meningkatkan Hasil Belajar Siswa Kelas Vii a Pada Sub Pokok Bahasan Keliling Dan Luas Bangun Segitiga Dan Segiempat Di SMP Negeri 1 Ajung Semester Genap Tahun Ajaran 2012. Jurnal Pancaran, 3(2), 2. https://doi.org/10.12816/0050333

Hasanah, N. F., Nurtaman, M. E., \& Hanik, U. (2019). Pengaruh Model Pembelajaran Kooperatif Tipe Rotating Trio Exchange (RTE) Terhadap Hasil Belajar dan Minat Belajar Matematika Siswa Kelas V Sdn Pinggir Papas 1 Sumenep. Widyagogik: Jurnal Pendidikan Dan Pembelajaran Sekolah Dasar, 6(2), 112. 
https://doi.org/10.21107/widyagogik.v6i2.5195

Isjoni. (2013). Pembelajaran Kooperatif Meningkatkan Kecerdasan Komunikasi Antar Peserta Didik. Yogyakarta: Pustaka Pelajar.

Jeranah. (2017). Efektivitas Penerapan Strategi Think Talk Write (TTW) dalam Pembelajaran Matematika Ditinjau Dari Gaya Belajar Siswa. Simposium Nasional MIPA Universitas Negeri Makassar, 138-146.

Karmila, \& Ekawati, D. (2016). Efektivitas Pembelajaran Matematika Melalui Model Kooperatif tipe STAD dengan Pendekatan Problem Posing. Pedagogy, 1(2), 76-85. http://journal.uncp.ac.id/index.php/Pedagogy/article/view/358

Muswaroh, S., Sukartiningsih, W., \& Subroto, W. T. (2018). Penerapan Model Pembelajaran Kooperatif Tipe Think Pair Share Berbantuan Media Puzzle Untuk Meningkatkan Keaktifan dan Hasil Belajar Siswa pada Mata Pelajaran IPS Kelas V SDN Soge Kandanghaur Indramayu. Jurnal Review Pendidikan Dasar : Jurnal Kajian Pendidikan Dan Hasil Penelitian, 4(2), 674. https://doi.org/10.26740/jrpd.v4n2.p674-685

Nuraeni, Y., \& Afriansyah, E. A. (2016). Peningkatan Kemampuan Pemahaman Matematis Siswa Melalui Pembelajaran Kooperatif Tipe Rotating Trio Exchange. Jurnal Inovasi Pendidikan Dasar, 1(2), 85-94. http://jipd.uhamka.ac.id/index.php/jipd/article/view/24/12

Nurhusain, M. (2017). Implementasi Model Pembelajaran Kooperatif tipe Numbered Heads Together (NHT) Terhadap Hasil Belajar Matematika Siswa Kelas XI IPA SMA Bajiminasa Makassar. Jurnal Panrita, 12(2), 279-289.

Pratama, P., Kamsiyati, S., \& Budiharto, T. (2015). Studi Komparasi Penggunaan Model Pembelajaran Kooperatif Tipe Rotating Trio Exchange (RTE) dengan Student Teams Achievement Division (STAD) Terhadap Pemahaman Konsep Bangun Ruang. Jurnal Didaktika Dwija Indria, 3(3), 1-6.

Rismawati, \& Jasman, J. (2014). Pengaruh Penerapan Metode Pembelajaran Kooperatif berbasis Kasus yang Berpusat pada Mahasiswa terhadap Efektivitas Pembelajaran Perpajakan. Jurnal Akuntansi, 01(02), 65-83.

Sadikin, A. (2017). Pengaruh Penerapan Strategi pembelajaran Rotating Trio Exchange terhadap Hasil belajar Mata Kuliah Dasar-Dasar dan Proses Pembelajaran Biologi Influence of The Application of Rotating Trio Exchange Learning Strategies On 
The Learning Outcomes of The BASIC. Biodik, 3(2), 73-80.

Sudjana, N., \& Ibrahim. (2012). Penelitian dan Penilaian Pendidikan. Bandung: Sinar Baru Algensindo.

Sundayana, R. (2015). Statistika Penelitian Pendidikan. Bandung: Alfabeta.

Tanujaya, B., \& Mumu, J. (2019). Implementation of Think Pair Share to Mathematics Instruction. Journal of Education and Learning (EDULEARN), 13(1), 510-517. DOI: http://dx.doi.org/10.11591/edulearn.v13i4.14353

Tanujaya, B., Prahmana, R.C.I., \& Mumu, J. (2017). Mathematics Instruction, problems, challenges, and opportunities: A case study in Manokwari regency, Indonesia. World Transactions on Engineering and Technology Education, 15(3), 287-291. Supriyadi. (2013). Strategi Belajar dan Mengajar. Yogyakarta: Dua Satria Offset. Wahyuddin, \& Erliani. (2019). Efektivitas Pembelajaran Matematika Melalui Penerapan Model Kooperatif Tipe Think Pair Share (TPS). JPM UIN Antasari, 06(1), 1-16. Widyawati, E., Poerwanti, J. I., Daryanto, J., \& Kamsiyati, S. (2016). Penerapan Model Pembelajaran Kooperatif Tipe Rotating Trio Exchange (Rte) Dalam Upaya Meningkatkan Kemampuan Menyatakan Lambang Bilangan Romawi. Jurnal Didaktika Dwija Indria (SOLO), 4(11).

Yahya, A., \& Bakri, W. N. (2020). Pembelajaran Kooperatif Tipe Rotating Trio Exchange Untuk Meningkatkan Aktivitas Dan Hasil Belajar Matematika Siswa. Jurnal Analisa, 6(1), 69-79.

Yuliati, Y., Baharuddin, \& Rafiqah. (2016). Penerapan Model Pembelajaran Kooperatif Tipe Rotating Trio Exchange ( RTE ) untuk Meningkatkan Hasil Belajar Peserta Didik pada Mata Pelajaran Fisika. Jurnal Pendidikan Fisika, 4(2), 100-103. 